\title{
Reprogramming of Urban Environment: the Work of Mohsen Mostafavi in London Architectural Association Between 1970s - 1980s*
}

\author{
Kseniya Malich \\ State Hermitage \\ St. Petersburg, Russia \\ E-mail: kseniamalich@gmail.com
}

\begin{abstract}
The paper deals with the profound heritage of Moshaven Mostafavi, one of the leading teachers at London Architectural Association at the end of 1970s - the 1980s, when he was the tutor for many students. London Architectural Association was one of the most influential architecture schools in the second part of the XXth century. First is because its radical change in the pedagogical process in 1960-s and unprecedented interest to the problems of architecture evolution and contemporary urban development. Among the students and teachers of AA were Rem Koolhaas, Zaha Hadid, Bernard Tschumi, Leon Krier, Daniel Libeskind, Nicholas Grimshaw, Steven Holl and many other outstanding authors. Moshaven Mostafavi, who graduated from AA in 1976, took an active part in preparing the new studying courses. Together with his students Mostafavi researched the opportunities for reprogramming of historical urban environment, looking for the new routes for contemporary architecture in frames of European cities.
\end{abstract}

Keywords-modernism; post-modernism; English architecture; London architecture association; Moshaven Mostafavi; architectural education; XXth century architecture

\section{INTRODUCTION}

It is impossible to speak about the formation and evolution of the contemporary architecture of the world without mentioning the history of the London Architectural Association of the 1970s - 1980s. Starting from 1963, when Alvin Boyarsky became the director of the association (1928-1990), educational programs and teaching methods were radically renewed. The system of blocks that involved working in self-organizing groups led to the emergence of a free and creative atmosphere that made possible the most audacious experiments. Boyarsky himself called the new practice a "well-laid table", served for "free souls", suffering from a "drought" reigning in traditional schools [1]. At different times, Nicholas Grimshaw, Rem Koolhaas, Léon

*The Reported study was Funded by Science and Technology Development State Program of the Russian Federation for years 2013-2020 Program of Fundamental Research of State Academies of Science for years 2013-2020, within the Program of Fundamental Researches of Ministry of Construction, Housing and Utilities of the Russian Federation and Russian Academy of Architecture and Construction Sciences; the Research Project 1.6 .6$.
Krier, Peter Cook, Daniel Libeskind, Cedric Price, Zaha Hadid, Bernard Tschumi and many other stars of contemporary architectural practice studied here or taught here. And not only practice, but first of all - the theory. The association tutors ${ }^{\text {ec }}$ work - articles, educational assignments, reviews - is still waiting for a thorough systematization. For any researcher who is not indifferent to the discoveries of the artistic underground of the 1960s-1980s (not only in architecture, but also in cinema, music, and literature), the community of London Architectural Association will be an genuine discovery. This study is dedicated to one of the tutors of the association - Mohsen Mostafavi - an architect, scientist, critic, historian, and publicist. The works of Mostafavi are well known and recognized by the international professional community.[2], [3] However, we will focus on one particular episode of his early educational work - the students ${ }^{\text {ee }}$ projects, which he supervised at the Architectural Association in 1978-1981, being a tutor together with Dalibor Vesely (Vesely was once Mostafaviees mentor).

\section{THE SENSITIVE GENERATION AND REPROGRAMMING OF THE URBAN ENVIRONMENT}

These years, Moshaven Mostafavies students worked on the project of reconstruction of the Kentish Town district in London. The quarters located to the northeast of Regents Park, north of Camden, belong to the historic part of the city and preserve the 19thcentury houses. After World War II, the necessity to renew district was discussed several times, but these plans were never implemented. A certain stagnation in the daily life of Kentish Town attracted the attention of Mostafavi, who offered his students a course assignment to develop a project for reorganization of the territory. Some of the finished projects were published later, and Alvin Boyarsky noted in his preface to the catalogue an important general principle: in their works, the students created entirely new urban situations, based on the poetic imagination on one

The author would like to express gratitude to former director of London Architectural Association Brett Steele and chief archivist Edward Bottoms for their help with this study, a detailed story the life of the Association in $1970 \mathrm{~s}-1980 \mathrm{~s}$, and for the opportunity to study the drawings and the commentary to them from the archive of the Association 
side, and on trying to restore the continuity of the local cultural tradition on the other.[4] Boyarsky uses the term "sensitive", and could characterize not only the projects of Mostafavi and Veselyes students, but the entire generation of the Association graduates of the 1970s.

This sensitive generation made it possible for the nuances that disappeared from the practice of post-war modernism to return to the architectural vocabulary. It was not just about rehabilitating the techniques of order architecture and the diverse heritage of historical styles. First of all, it was the sensitivity of associations, the receptivity of collective memory. The aim of the project was to return the original semantic and iconographic basis to the city, to reprogram the urban environment. Mostafavi and his colleagues argued about recreating the city as a traditional place for human life. It was no longer necessary to look for ideal urbanization formulas that corresponded with the level of technological development or progressive social reforms (this modernist attitude was categorically rejected). It was assumed that all the fundamental foundations of the joyful functioning of the urban organism had already been created, they only needed to be found and "revealed" in the cultural layer.

It is noteworthy that as such a foundation, students and tutors of the Architectural Association often studied the mechanisms that appeared in the late medieval era, that is, during the birth of the very phenomenon of the "European city". We should keep in mind that the late 1960s was the end of the post-war reconstruction of Europe, when protectionist policies and the strict hierarchy of the centralized state urban planning was the fastest possible way to overcome the consequences of World War II. Many mistakes that were made during the reconstruction of historical centres and the construction of new residential districts discredited the universal methods of the International style. At the same time, the socio-demographic situation also changed significantly. The generation of "baby boomers" that came of age and did not want any custody was looking for cheap housing in the centre - in dormitories, squats, or old houses. They needed the urban chaos that Jane Jacobs wrote about: chaos, which is endowed with an incomprehensible order, life force and wisdom, in which the core of social life is more likely to be a local merchant's shop and not an intentionally planned centre.[5] Instead of the "planned" urban design of the first half of the 20th century, which proposed the final state of the city, the "collective will of the town-builders"[6] flexibly controlling the real processes of urban development in the Middle Ages, was needed again.

In the preface to the same catalogue of Kentish Town projects, Vesely's associate Peter Carl noticed that starting from the Renaissance, there was a process of intense diffusion of the mythological material that gave birth to architecture and urban topography.[7] The author emphasized that since the 8th century, we no longer perceive elements of order architecture from the point of view of their mystical, religious, ontological origin. The notion of classics transformed and was rediscovered so many times that in the general opinion everything reduced to certain common typologies and forms. As a result, by the end of the 19th century, the city turned into just the visible historical landscape, a cultural encyclopaedia without functions. The loss of semantic landmarks in the perception of architecture has become the key problem of contemporary urban planning. At the same time, architecture as a summarizing kind of artistic practice is involved in all spheres of life, and thus, the city has been creating a fundamental symbolic and semantic reality for centuries. Up from the Middle Ages, the city by its nature in fact symbolized cultural integrity based on diversity. Contemporary history, and Modernism in particular, so classified the reality so desperately that threatened the cultural continuity because they missed the main point - the connections between the history of reality and the history of consciousness. But the contemporary architect, according to Mostafavi, was able to restore the remaining rudiments of these origins of architecture and urban topography. One had to work partly as an archaeologist, partly as a specialist in reconstruction.

\section{KENTISH TOWN}

So, accepting the thesis that architecture is a mimesis of some exemplary and collectively imagined situations inherited from the past, Moshaven Mostafavi offered his students to come up with a new urban environment in which there would be a place for the most important urban archetypes - agora, necropolis, monastery, marketplace. The city of the centre was the Forum, seen both as the main square and as a starting point generating life around itself. Here, students tried to recreate the importance of the centre as a place, without which the periphery loses its significance. This is not just a geographical location, but the Omphal (the navel of the world, a stone dedicated to Apollo in the Delphic temple), or the Mundus (a pit in ancient Rome, believed to be dug by Romulus and marking the entrance to the realm of the dead), or the Tholos (a meeting place at the Athenian Agora, storage of measures and weights). However, although the forum designs by Eric Parry, Sima Farjadi, Dan Stranescu carry an image of the ancient origin (the gate in the form of tholos, dais), but their topography refers to the medieval tradition. The city square, first of all, reconciles, unites and ensures the diversity of roles and opportunities. The theatre, the city administration, the dance school, the library, the residential house, the garden of delights, the necropolis, the exhibition hall are connected with the forum. Public practices and rituals (starting with the theatre and commerce, and up to politics and death) in the $18^{\text {th }}-20^{\text {th }}$ centuries were gradually suppressed and taken to the buildings not to be visible from the street. Mostafaviees students try to compensate for this disastrous transformation, integrating different zones into a single space. Buildings open to the asymmetric field of the forum, the foyer of the city, with arcades, multi-span staircases and galleries. The polyphony is continued by the promenade, which strats from the north side of the forum and goes along the railway tracks (Iolanda Stranescues project).

Just as in the Middle Ages the city appeared due to the emergence of conditions allowing social and economic practices to meet, [8] in the situation created by students, in the foyer, the most polar functions reconcile (which bring 
back the desired diversity to the city). The medieval city rehabilitated many professions, gave not only a sense of personal freedom to the new citizens, but also "the sharpness of property contrasts and social contradictions", "a range of connections with the outside world", openness, carnival, interlacing and disengagement. [9] So Kentish Town appears as both as an imago mundi and as a theatrum mundi (the image of the world and the theatre of the world), it is a scenography for a full-blooded and unpredictable life. It is no accident that the building of the Theatre became the organizational centre of the complex. And in the projects by Dan Stranescu and Vasos Veneris the theatre has an external stage, which makes the surroundings act as a theatrical scenery. Gable pediment, high semicircular windows and niches that unify three floors, three-part windows - while these elements do not directly quote classical architecture, they certainly refer to it. There is no attempt to imitate or copy the past in these approaches: it rather testifies the search for the refinement of the genuine old, destroyed, but still grandiose.

The Kentish Town main square is connected with the Necropolis. Mostafavies students tried to recreate not the cemetery itself, but a sign of fate, a symbol of universal destiny, which is necessary to remember if we want to give meaning to life itself. Athanasios Spanomaridis, referring in the description of his project to Marc-Antoine Laugier, emphasized that the gradual relocation of cemeteries outside of the European city (for hygienic and practical reasons) in the Modern history deprived the citizens of the most important symbolic element.[10] We can also add that the practice of bringing the dead to the city appears in the Middle Ages (in the Antiquity it was preferred to make burials along roads). Cemeteries, necropolises, and, finally, the tradition of worshiping holy relics and associated pilgrimage routes - all these phenomena refer to the evolution of the medieval European city in which the living and the dead formed a single community. Georges Duby even called Christianity around $1000 \mathrm{CE}$ "the religion of the dead".[11] The memory of a person then was equivalent to his participation in the life of the urban community.[12]

In the project by student Kaveh Mehrabani a street crosses the necropolis: specially to promote the integration of the funerary complex into the citizens ${ }^{\text {ee }}$ everyday life. In Sima Farjadies project, a key place is given to the Takht, a symbol borrowed from the Indian Sikhs. The Takht represents the sacred mountain reaching the sky, and in Farjadies project is placed between two polar spaces - the nightingale garden and the prison. In Spanomaridises prjoect, the necropolis is depicted in the form of a castle inhabited by ghosts in Renaissance clothing. The central building is a structure resembling a tholos with rings of burial vaults and tombs around it. Originally, the tholos in the Western tradition was really connected with the tomb, the eternal fire and the idea of rebirth. Moreover, the centric form was one of the most persistent in the European architectural typology. Spanomaridis imagines the project with a clear reference to the architecture of the Roman Colosseum, however, here the multi-tiered arcades are supplemented with a dome.
Another group of buildings was represented by more lifeoriented typologies - the shopping center, residential buildings, the library, the building for politicians. The latter was understood not so much a building with an administrative function, but rather as a space for conversations, debates, and discussions. Eric Parryes design includes a hall and two public meeting rooms. Then the house coalesces with other urban public resources: a lecture hall, an exhibition area, a bookstore, a cafe, a gallery, a rhetoric academy, a club, a cabaret. The unifying pattern in this part of the project consisted not of repeating elements, but on the contrary - the spaces that Mostafavi treated as an independent architectural means. [13] The project has the conditions for maximum possible interpenetration of all zones via galleries and gardens. Internal sun tubes, frequent spatial breaks, endless rows of arcades and roofed galleries refer to the design and layout of medieval monastic and university complexes.

Working on the residential house project, Kaveh Mehrabani, Vasos Veneris, Shahriar Nasser, Mohammad Farzan make an attempt to recreate the hierarchy of the entire city complex. The first floor and the entrance area are connected with the street as much as possible the living room is made as a kind of forum. Further space becomes more enclosed and intimate; living rooms are hidden behind internal cloisters. Kalliope Kontozoglou makes the street penetrate the house through the wind porch and the foyer, then spin on the stairs, and spread through the distant rooms. One of the most popular forms in the Kentish Town project is an axonometric section that reminds an archaeological scheme. Axonometry allows you to catch the flow-through motion, passing through the whole project, from the underground depths - to the sky. Dozens of additional junctions and galleries girdle the buildings like threads, making us compare the projects with wormholes. Here, the solutions found by the students of the Architectural Association remind us of the Structuralists, who succeeded in implementing a number of successful projects in the late 1960s-1970s. These issues are particularly clearly articulated in the works by the Netherlands architects - Aldo Van Eyck, Herman Hertzberger, Piet Blom. Balconies, roofed passages, doors with a separately opening upper part and many other forms of transit space made it possible not only to maintain and stimulate social contacts, but to create conditions for private life and at the same time reconcile bordering worlds. After all, as Herman Hertzberger once wittily noted, passengers in a plane sit very closely to each other, but the closeness itself barely contributes to communication. [14]

The students believed that the concept of a contemporary shopping center killed the picturesque disorder that appeared in the European cities in the Middle Ages.[15] While originally the street developed due to spontaneous commercial activity, and every store and workshop was directly connected to the outside world, shopping arcades and department stores contributed to the atrophy of communication. For this reason, in the projects of the shopping center for Kentish Town by Kalliope Kontozoglu and Iannis Zachariades, the first floor is given to the retail trade. There is also an "encyclopedia wall", where different 
objects (from scales to a guillotine) are placed in niches, telling the history of urban trade. A reminder of the origin of the city should have helped the citizens to overcome their shortsightedness, expand the horizons of iconographic perception.

\section{CONCLUSION}

Three sites can be considered the main semantic victories in the renovated Kentish Town - the astrophysicist "s library, the gardens of delight and the monastery. These sacred topoi symbolized the cultural heritage that still has a colossal "symbolic power."[16] In Paul Jones's sketches, the astrophysicist's library continued the tradition of a philosophical cave, the dwelling of a hermit sage. While the central place in the library is given to the marble hall full of light for scientistse meetings, all the other rooms (the planetarium, laboratories, the observatory) are reduced to the size of a monastic cell. On the contrary, the monastery is drawn as open and democratic as possible. Life comes here in the form of workshops, a bakery, a hostel, a music hall. Finally, the gardens of delight passing through all the zones of Kentish Town are a tribute to the medieval locus amoenus - a place of joy, idealized comfort and peace.

Stone of different texture and different ways of the plaster processing make this kind of a maze look natural. They make the architecture look like it has existed for a very long time, they set a temporal variable, which, according to the association, the contemporary architecture should not lose. According to the famous words by Mostafavi himself, "finishing ends construction, weathering constructs finishes". [17] (Mark Wigley later treated the collage made from old urban fabric patterns as space clothes [18]). The instability, which the modernists were so afraid of, and which, indeed, for centuries was overcome with the help of the "classical" model, a demanded tool of the architect. It is no accident that the 1970s architectural community saw a rehabilitation of the Art Nouveau methods. For example, in one of the newspapers, which were issued at this time by the Architectural Association, there was a review of the exhibition of works by Gustave Guimard. The article accused modernism of neglecting the decorative side of Art Nouveau. In the authors' opinion, it was precisely that decorative side that contained the true rational basis of architectural design, in contrast to the abstract techniques of neoclassicism.[19] At the same time, the anti-classicist set of mind did not prevent the students of the association from using quotes from such authors as, for example, Ledoux and Boullée. Thus, in Paul Jones 's project of the astrophysicist's library, the meditative space partly recreates the image of Newton's cenotaph by Étienne-Louis Boullée.

The graphics by Mostafavies students is especially detached. There is practically no staffage in the drawings, there is active light-shadow modeling, architecture is exposed to its origins, appears on the sheets as a mirage, as a metaphysical reality on the canvases of De Chirico. This comparison is not too farfetched, given the curiosity with which the Architectural Association in the 1970s studied the heritage of the European surreal painting.[20] Surrealism seemed to be the ideal keeper of the cultural tradition, and at the same time the direction that, as a litmus test, revealed the crisis of modern culture, distortion and substitution of human values. And of course, the methods of the surrealists seemed to be very relevant, referring with uncompromising radicalness to archaic experience and mythology. In the late 1970s, in the Architectural Association, as elsewhere in the world, the architects were engaged in collecting a cultural crop. They looked like archaeologists discovering the forgotten truths.

\section{REFERENCES}

[1] I. Sunwoo. From the ,well-laid table $e^{\text {ee }}$ to the ,marketplace:e The architectural association unit system // Journal of Architectural Education 65, No. 2 (2012), p. 30.

[2] D. Leatherbarrow, M. Mostafavi. On weathering: the life of buildings in time. Cambridge, Mass.: MIT Press, 1993.

[3] M. Mostafavi. Ecological urbanism. ars M ller Publishers, 1 .

[4] A. Boyarsky. Forward // Architecture and continuity. Kentish Town Projects 1978-1981. Diploma Unit 1. London: Architectural Association, 1982, p. 3.

[5] J. Jacobs. The death and life of great American cities / Jane Jacobs. New York: Modern library books edition, 1993, p. 63, 443.

[6] A. V. Ikonnikov. Prostranstvo I forma v arhitekture I gradostroitelstve. -2006, p. 217-218.

[7] P. Carl. Preface // Architecture and continuity. Kentish Town Projects 1978-1981. Diploma Unit 1. London: Architectural Association, 1982 p. 6-7.

[8] J. Rossiaud. Le citadin // L'homme médiéval, dir. Jacques Le Goff, Paris, Le Seuil, 1989, p. 159-200.

[9] A.Ya. Gurevich. Kategorii srednevekovoy kultury. Moscow: Iskusstvo, 1972, p. 178.

[10] M.-A. Laugier. Observations sur l'architecture. 1765. Réédition de Geert Bekart. Liège. P. Mardaga, 1979, p. 174.

[11] G. Duby. Les trois ordres ou l'imaginaire du feodalisme. Paris, 1978, p. 55.

[12] A.Ya. Gurevich. Kategorii srednevekovoy kultury. Moscow: Iskusstvo, 1972, p. 242.

[13] M. Mostafavi. Ecological urbanism. ars M ller Publishers, 1 , p.

[14] H. Hertzberger. Lessons for students in architecture. - 2001, p. 212.

[15] R. S. Lopez. The commercial revolution of the Middle ges, 1 . ambridge University Press, 1 6, p.

[16] J. Pendlebury. Conservation in the Age of Consensus / John Pendlebury. - Oxford: Routledge, 2008, p. 150.

[17] D. Leatherbarrow, M. Mostafavi. On weathering: the life of buildings in time. Cambridge, Mass.: MIT Press, 1993, p. 5.

[18] M. Wigley. Architecture after philosophy: Le Corbusier and the Emperor's new paint // Philosophy and Architecture, ed. Andrew Benjamin. Journal of Philosophy and Visual Arts. no 1. London: Academy Editions, 1990, p. 89.

[19] Chost dance times, 18 October, 1974, p. 1.

[20] Architecture and continuity. Kentish town projects 1978-1981. Diploma Unit 1. London: Architectural Association, 1982. P. 7. 